Leszek Augustyn

Kraków, Uniwersytet Jagielloński w Krakowie

\title{
Kultura transcendencji: czas egzystencjalny w ujęciu Mikołaja Bierdiajewa
}

\section{Culture of Transcendence:}

Existential Time in the Thought of Nikolai Berdyaev

\begin{abstract}
The article deals with the issue of time (the temporality of existence) in the philosophical thought of Nikolai Berdyaev. The problem of the relationship between the two dimensions of the experience of time, namely the experience of historical time and existential time, was taken up in it. In other words: the problem of "temporalizing" the existence of the world and man, as well as defining the relationship of time with such categories as eternity, freedom, and creativity. The reflection has been centered on the philosophical meaning of time in terms of (expression, understanding) the existential character of human existence in the world.
\end{abstract}

Keywords: Nikolai Berdyaev, Russian philosophy, history, time, existence

Problematyka czasu - czasowości istnienia - zajmuje w myśli filozoficznej Mikołaja Bierdiajewa miejsce poczesne, a nawet mocno wyeksponowane. Otóż przekraczając próg myśli rosyjskiego filozofa, próbując zarysować „schemat" problemu czasowości istnienia, można i należy mówić o relacjach, jakie zachodzą między dwoma różnymi wymiarami doświadczenia czasu, a mianowicie - istnienia w czasie historycznym i w czasie egzystencjalnym. Innymi słowy: rzecz przez nas roztrząsana będzie się tyczyć problemu „uczasowienia” istnienia świata i człowieka, co będzie również domagało się określenia charakteru relacji czasu do równie zasadniczych, co i on kategorii, jak: wieczność, wolność i twórczość. Jest to problematyka stale rozwijająca się $w$ ramach intelektualnej biografii myśliciela i ani na krok nie odstępująca filozofa do ostatnich dni jego życia. Rozważane zagadnienie wymaga zatem ześrodkowania namysłu na metafizycznym i antropologicznym 
wymiarze czasu, skupienia naszej uwagi na czasowości istnienia człowieka w świecie. Wszak Bierdiajew jednoznacznie podkreślał, że zagadnienie czasu jest problemem podstawowym dla sprawy istnienia ludzkiego'.

\section{Egzystencja i kultura}

Na wstępie trzeba powiedzieć, z czym nie krył się rosyjski myśliciel, że styl jego filozofowania, sposób ujmowania problemów i rozwijania zagadnień opierają się na myśleniu paradoksalnym; ten zaś sposób uprawiania przez siebie filozofii określał mianem dialektyki egzystencjalnej. Uważał się za myśliciela chrześcijańskiego, i tak też był najczęściej postrzegany. (Zresztą należałoby przyjąć, że w pewnym sensie dialektyka łączy się z chrześcijaństwem; biorąc lekcję u Hegla można by nawet powiedzieć, że samo chrześcijaństwo jest dialektyczne ${ }^{2}$. Co prawda, wczytując się w niestroniące od paradoksalności pisma Bierdiajewa, nie słyszymy aż tak radykalnego jak u Sørena Kierkegaarda wezwania do stawania się „pojedynczym”, „współczesnym z Chrystusem”, niemniej jednak uznawał on swoją filozofię za myślenie stricte egzystencjalno-chrześcijańskie ${ }^{3}$. Na gruncie filozofii walczył więc o "przebóstwienie” (theosis) ducha ludzkiego, widząc w nim przede wszystkim możliwość jego wyzwolenia.

Dość powiedzieć, że Bierdiajew uprawiał filozofię „wolnego ducha”, a zatem calkowicie obca była mu powściągliwość wobec sztywnych ortodoksji i pilnie strzeżonych granic; rzec można, że nie tolerował policjantów myśli. W tkankę zaś swojej własnej myśli i to w samo jej jądro, wprowadzał elementy gnozy chrześcijańskiej. Ten stop nader różnych tradycji (oraz kłanianie się powstałym na ich łączeniu „mitom") wytykał mu bliski przyjaciel i wybitny myśliciel, Lew Szestow. Wierny dość młodej jeszcze tradycji rosyjskiej filozofii religijnej, zakorzenionej w myśli Włodzimierza Sołowjowa, uczynił zwornikiem swego stanowiska „mit podstawowy”

Н.А. Бердяев, Я и мир объектов. Опыт философии одиночества и общения, [w:] idem, Духи реальность, Москва 2006, s. 106 (wyd. pol. Rozważania o egzystencji. Filozofia samotności i wspólnoty, przeł. H. Paprocki, Kęty 2002, s. 71).

2 Por. L. Dupré, Inny wymiar. Filozofia religii, przeł. S. Lewandowska-Głuszyńska, Kraków 2003, s. 14.

3 W naszym kontekście owocne będzie przywołanie słów duńskiego myśliciela: „Bowiem w stosunku do tego, co absolutne, występuje tylko jeden czas: teraźniejszość; dla tego, kto nie jest współczesny $z$ tym, co absolutne, to, co absolutne, w ogóle nie istnieje. A ponieważ Chrystus jest tym, co absolutne, łatwo zauważyć, że wobec Niego możliwa jest tylko jedna sytuacja: sytuacja współczesności [...]". (S. Kierkegaard, Wprawki do chrześcijaństwa. Anti-Climacusa nr I, II, III, przeł. A. Szwed, Kęty 2002, s. 62). 
dla chrześcijaństwa, w którego centrum znajdowała się i który wypełniała swoją treścią idea Bogoczłowieczeństwa - największy paradoks, wyznaczający również Bierdiajewowski sposób myślenia ${ }^{4}$. To tutaj możemy się doszukiwać źródeł przywiązania rosyjskiego filozofa do paradoksalności i jego skłonności do „mitologizowania" myśli filozoficznej.

Należy również zauważyć, że pewna odpowiedniość, a nawet niekiedy pokrywanie się struktur myślenia gnostycznego i egzystencjalnego (na co wskazywał Hans Jonas), jest w obu tradycjach uderzająca i dająca wiele do myślenia. Podobnie jest u Bierdiajewa. $Z$ naszego punktu widzenia wynika stąd sprawa zasadnicza: człowiek to istota "upadła" w czas, niemieszcząca się w nim do końca, "tęskniąca" za czymś więcej i „wyrywająca się" spod władzy czasu. Sytuacja "upadku” wskazuje jednak na istnienie sfery pierwotniejszej, wyższej i doskonalszej, do której świadomy własnej pozycji w kosmosie i historii człowiek nie tylko odnosi się (jako do miary swego "upadku”), ale i na którą może ukierunkować swoje dążenia i działania.

$Z$ tego punktu widzenia wolne i twórcze „wychodzenie poza” istnienie czasowe (ex-sistere w sensie: 'znajdować się poza, na zewnątrz') jest wkroczeniem w sferę wolności poprzedzającej byt, dotknięciem wieczności leżącej u podstaw cza sowości i oddaniem się t wórczości przekraczającej zastaną kult u rę. Człowiek jest pogrążony w czasowość swego istnienia - pozostaje to prawdą, którą nie sposób podważać, jednakże zarazem w swym podstawowym dążeniu ukierunkowuje się w stronę wieczności. Tworzoną przez niego kulturę należy więc pojmować jako "miejsce" czasowienia istnienia i jednocześnie jako zapis „wychodzenia" poza czasowość. Określmy to mianem: aktowości istnienia w kulturze. Przy takim zaś podejściu dostrzegalny jest wewnętrzny paradoks, który sprowadza się do stwierdzenia, że transcendencja jest immanentna. Otóż właściwym przeciwieństwem podmiotowego ukierunkowania ku transcendencji nie jest immanencja, lecz obiektywizacja, czyli uprzedmiotowione odpodmiotowienie świata ${ }^{5}$. Wychodzenie poza czas, samo już przekraczanie poziomu czasowości, jest bowiem wpisane w ludzki porządek przeżywania czasu. Czy na tym więc polegałoby właściwe człowiekowi bycie-w-czasie? Nie tylko Heideggerowska „troska”, lecz i Marcelowska „nadzieja"6?

4 Н.А. Бердяев, Экзистенциальная диалектика Божественного и человеческого, [w:] idem, О назначении человека, Москва 1993, s. 280 (wyd. pol. Egzystencjalna dialektyka Boga i czlowieka, przeł. H. Paprocki, Kęty 2004, s. 39).

Por. idem, Экзистенциальная..., s. 322 (wyd. pol., s. 94).

Por. M. Heidegger, Bycie i czas, przeł. B. Baran, Warszawa 2008; G. Marcel, Homo viator. Wstẹp do metafizyki nadziei, przeł. P. Lubicz, Warszawa 1984 (zwłaszcza rozdzial: Zarys fenomenologii i metafizyki nadziei). 
Nie zważając na możliwe zastrzeżenia, Bierdiajew pozostaje nieugięty w swoim przekonaniu, że człowiekowi jest dana możliwość przekraczania poziomu „światowości": wychodzenia poza - doczesny, czasowy - świat. Wypada też przyjąć, że historia i kultura, a zatem kulturalna historia ludzkości, tworzą szczególną sferą symboliczną, w której czas zostaje poddany obiektywizacji (wszak kulturę tworzy się w czasie: walcząc z czasem); poniekąd można więc przychylić się do twierdzenia, że tak ujmowana kultura stanowi „Czas zastygły” i przyjmuje postać zobiektywizowanych rezultatów twórczości ludzkiej - ale nie wyłącznie, i to trzeba wyraźnie podkreślić. Jest bowiem równocześnie zapisem ludzkiego „wychylenia” ponad historię, wychodzenia ku wieczności; inaczej mówiąc: przekraczania zwykłego porządku czasowego. Nie można zatem zapominać, że u samych źródeł czasowości - ujmując to obrazowo - „pulsuje” niezobiektywizowana, niepodzielna i nieprzemijalna wieczność: „prawdziwa” wolność.

Na marginesie zaś tych uwag dodajmy, że w myśleniu Bierdiajewa pojawia się również klasyczny problem (pierwotnej) jedności i (pochodnej) wielości. A skoro pojęcie „wieczności” daje się - przy pewnych istotnych zastrzeżeniach - używać naprzemiennie i zamiennie z pojęciem „wolności”, to z kolei pojęcie „czasu” wiąże się $\mathrm{z}$ ograniczeniem: bycie $\mathrm{w}$ czasie to istnienie umniejszone $\mathrm{w}$ swych możliwościach, niedoskonałe, niemogące posiąść swej pełni. Nie bez powodu przecież mówi się o "upadku w czas". Kultura świadczy o (dążeniu do) wieczności. Ujmowana i rozważana pod kątem eschatologiczności, poza ściśle własną perspektywą, przynależy już częściowo i jeszcze nie w pełni do wieczności. Właściwie jednak mówiąc, nigdy takiej całości nie osiągnie: dopiero pozostawiając osad fałszu, pozorów i zbłądzeń aksjologicznych, ostatecznie osądzona, przejdzie w stan metahistoryczny. Obecnie zaś posiada swą własną historię, rozciąga się w czasie, akumuluje swoje osiągnięcia. Ujmowana sama w sobie jest tedy „złą nieskończonością”: ślepą, niekończącą się w czasie nieskończonością. W niej czas nie może się skończyć i w tym właśnie sensie kultura nie posiada żadnego zwieńczenia.

\section{Człowiek zanurzony $w$ czasie}

Człowiek jest istotą paradoksalną, gdyż łączy w sobie wieczność i czas. Od początku istnienia nosi w sobie „obraz Boży”, ale równocześnie jest zanurzony w rzece czasu i historii: heraklitejskim świecie płynności. Wyłącznie ślepiec może pomylić zwykłe przemijanie $\mathrm{z}$ prawdziwym, duchowym rozwojem. Istnieje zatem „zły" i „dobry” czas. Fenomenalny i noumenalny, „zdrowy” i „chory”. Powyzsze rozróżnienia świadczą o tym, że de facto żyjemy w czasie "upadłym". Pociąga to za sobą poważne skutki. Czas „chory” odrywa bowiem historię od meta- 
fizyki ${ }^{\top}$. W konsekwencji "choroba” czasu polega na niemożliwości przeżycia pełni (wieczności) w teraźniejszości ${ }^{8}$. Tak rozumiana choroba dotyka czasu w każdym jego „momencie”, w którym - zamiast otwarcia na wieczność - doświadcza się nieprzekraczalnej skończoności porządku czasowego, zwykłego przemijania, „upadania" w czas. Historia ludzkości, w tym zwłaszcza mit biblijny, świadczy o powszechnej świadomości tego stanu rzeczy. A mimo to doświadczenie wieczności w czasie jest możliwe. Staje się dostępne w ekstatycznej, wytrąconej z porządku następstwa czasowego "chwili": każda taka chwila „pozostaje w wieczności”, zaś sam podmiot w swoim uczasowionym istnieniu przemija?

Oczywiście człowiek żyje zarówno w naturze, jak i w kulturze, po części więc w zmaganiach z naturą ludzkość buduje swój świat kultury, tworzy własną historię. W związku z takim „umiejscowieniem” człowieka i ludzkości należy też przyjąć $\mathrm{z}$ historycznego punktu widzenia dające się rozdzielić, $\mathrm{w}$ istocie zaś równolegle współwystępujące - trzy rodzaje czasu. Czas kosmiczny posiada postać cykliczną, czas historyczny - przyjmuje formę liniową, natomiast poniekąd amorficzny czas egzystencjalny - wyznacza ukierunkowanie "w głąb”, wiąże się z wymiarem duchowym i osobowym ${ }^{10}$. Temu ostatniemu poświęcimy naszą szczególną uwagę. Otóż czas egzystencjalny odnosi się do rzeczywistości wewnętrznej: „znajduje się” w człowieku. To nie człowiek zanurza się w czasie i poddaje jego zewnętrznemu porządkowi (o czym zaświadczają pospołu czas kosmiczny i historyczny), lecz sam czas pozostaje zależny od człowieka i jego uposażenia duchowego, ukierunkowania na wieczność. Wyłącznie czas egzystencjalny przynależy istotowo do człowieka, niemniej jednak nie można pozostawiać na uboczu innych wymiarów czasowego doświadczania istnienia (chociaż i kosmos, i historia na tę „uboczność" niejako się skazują). Można rzec, że historia ludzkości, wprowadzając kosmos w obręb swojego stawania się, czyni go częścią własnych dziejów.

O wiele bardziej złożony i szczególny związek zachodzi między historią i egzystencją. Filozofia historii dotyczy sposobu rozumienia czasu; innymi słowy, jest przede wszystkim filozofią czasu". Tak więc na "gruncie" czasu historia łączy się z egzystencją, a wymiar powszechny z perspektywą indywidualną. Czyżby więc kluczem do rozumienia historii ludzkości była płaszczyzna wyznaczana przez

Н.А. Бердяев, Смысл истории. Опыт философии человеческой судьбы, Paris 1969, s. 92 (wyd. pol. Sens historii. Filozofia losu czlowieka, przeł. H. Paprocki, Kęty 2002, s. 54).

Idem, $Я$ и мup..., s. 110 (wyd. pol., s. 74).

Idem, Опыт эсхатологической метафизики. Төорчество и объективация, [w:] idem, Царство Духа и царттво Кесаря, Москва 1995, s. 265 (wyd. pol. Zarys metafizyki eschatologicznej. Twórczość i uprzedmiotowienie, przeł. W. i R. Paradowscy, Kęty 2004, s. 142-143).

10 Ibidem, s. 263 (wyd. pol., s. 140).

"Ibidem (wyd. pol., ibidem). 
czas egzystencjalny? W tej kwestii odwołajmy się wpierw do poglądów Paula Tillicha, teologa i filozofa. Otóż wprowadzając pojęcie kairos, rozumiane przezeń jako „wypełnienie historii” w sensie nowotestamentalnym, a zatem stanowiące "przełomową centralną manifestację Królestwa Bożego", myśliciel ten czyni niezwykle ważne - nie tylko zresztą w naszym kontekście - rozróżnienie, a mianowicie przyjmuje "wielki kairos", przez co rozumie "pojawienie się centrum historii”, oraz pomniejsze kairoi, czyli partykularne manifestacje Królestwa Bożego ${ }^{12}$. Ujęcie takie dość dobrze koresponduje z poglądami Bierdiajewa, któremu zresztą nie była obca wczesna wersja Tillichowskiej „teologii historii"13.

W tym kontekście przywołajmy chociażby łączącą w sobie sens eschatologiczny i egzystencjalny następującą uwagę: „Eschatologiczna perspektywa to nie tylko perspektywa nieprzewidywalnego końca świata, jest to również perspektywa każdej chwili życia. W każdej chwili życia trzeba kończyć ze starym światem i rozpoczynać świat nowy"'14. Chodzi zatem o to, aby czas życia nieustannie otwierał się na to, co nowe (rzecz jasna nie w sensie progresywistycznym). Myśliciel bowiem wie dobrze, że prawdziwie odnowicielski może być tylko duch: wieczność „odwiecznie młoda"; natomiast czas "upadły" to tylko postępująca starość z kostuchą w tle. Ponadto trzeba uznać, że wcielenie Boga jako wydarzenie w swej istocie metahistoryczne dokonało się w czasie egzystencjalnym. Tillichowski sens „wielkiego kairo$s u$ " zbliżałby się zatem do Bierdiajewowskiej idei Wcielenia, odpowiadałby mitowi "uczłowieczonego Boga". Nie tracąc jednocześnie nic ze swojego - cokolwiek by sądzić, zbliżonego do myśli Kierkegaarda - egzystencjalnego znaczenia „chwili” religijnej, myślenie rosyjskiego filozofa wytycza jednak własną (historyczną) ścieżkę. Tak więc przywołując filozofa duńskiego, Bierdiajew utrzymuje, że przeżywanie chwili jako „atomu wieczności” umożliwia wyjście poza „potok czasu”, przekroczenie sideł obiektywizacji ${ }^{15}$. Tym sposobem możemy również przejść od opisu „zanurzenia" w czasie do doświadczenia „przeniknięcia” czasem.

\section{Człowiek przeniknięty czasem}

Przyjrzyjmy się strukturze czasu, $\mathrm{z}$ jaką spotykamy się w potocznym doświadczeniu ludzkim. Znany nam wszystkim trójwymiarowy podział czasu należy ujmo-

12 P. Tillich, Teologia systematyczna, t. 3., przeł. J. Marzęcki, Kęty 2005, s. 328-330.

13 Н.А. Бердяев, Дух и реальность. Основы богочеловеческой духовности, [w:] idem, Дух и реальность, Москва 2006, s. 350.

it Idem, Onbım..., s. 286 (wyd. pol., s. 169; cytat według polskiego przekładu).

15 Idem, Дyx..., s. 358. 
wać, odwołując się do rozważań św. Augustyna (a może raczej: do opisu doświadczenia czasowości, której dał on wyraz w XI księdze Confessiones), a mianowicie jako teraźniejszość przeszłości, teraźniejszość teraźniejszości i teraźniejszość przyszłości. I znów można mówić o paradoksie czasu, ale tym razem paradoksie osobowego doświadczenia czasu: „los człowieczy” (osobowość) spełnia się w czasie „rozbitym” na przeszłość i przyszłość (teraźniejszość wydaje się tylko wychyleniem w dwóch kierunkach), a zarazem obydwa te wymiary istnieją tylko w teraźniejszym doświadczeniu losu ludzkiego ${ }^{16}$. Przeszłość i przyszłość - te dwa wymiary wyznaczają zatem stosunek człowieka do własnej teraźniejszości.

W uobecniającej się teraźniejszości przyszłość odnosi się do przeszłości, a być może lepiej powiedzieć - przeszłość odnajduje się w przyszłości. Otóż w przeszłości należy rozróżniać to, co bezpowrotnie już odeszło, oraz wspomnienie, czyli przeszłość twórczo przemienioną przez ludzką teraźniejszość. Przy takim ujęciu problemu pamięci filozof rosyjski zbliża się do Bergsonowskiego rozróżnienia między nawykiem jako „czynnością automatyczną” i wspomnieniem jako „pamięcią par excellence" ${ }^{\prime \prime}$. Konserwatywny stosunek do przeszłości stara się zachować jej kształt niezmieniony, a tym samym uwiecznić jej niedoskonałość, natomiast twórcze podejście wprowadza przeszłość „w przyszłość i w wieczność”. Z jednej bowiem strony to, co niedoskonałe i grzeszne w przeszłości, zasługuje na zapomnienie i odrzucenie w niebyt, $z$ drugiej zaś - to, co w niej było dobrego, powinno zostać zachowane w pamięci i twórczo podjęte, a właściwie mówiąc: uwiecznione.

Tymczasem nieprzemieniona przeszłość niesie w sobie ciężar śmierci, którym przygniata teraźniejszość i przyszłość. Jedynie wejście w głąb - dążenie ku wieczności - może zatem zerwać ów śmiercionośny związek: oczyścić ze złogów „złego” czasu. Właściwe życie przebiega i narasta $\mathrm{w}$ czasie egzystencjalnym. O ile więc pamięć przyobiecuje "pełnię czasu”, o tyle zapomnienie wiąże się z „negacją czasu”; co też ostatecznie składa się na dwie strony tej samej obietnicy przezwyciężenia choroby czasu w wieczności ${ }^{18}$. Prawdziwego rozwiązania należy zatem upatrywać w wieczności, która będąc źródłem, jest i ujściem dla strumienia „upadłego” czasu. „Uzdrowienie czasu jest wiecznością" - przekonuje Bierdiajew ${ }^{19}$.

W doświadczaniu siebie istniejemy „chwilowo”; rzec można: od chwili do chwili. Czas zaś ujmowany sam w sobie przepływa zawsze „obok”, znajduje się na zewnątrz podmiotu i tak naprawdę nigdy nie zakorzenia się w przeżyciu wewnętrznym. W tym więc sensie czas i przeżywanie losu człowieczego w świecie

\footnotetext{
16 Idem, Я и мup..., s. 108 (wyd. pol., s. 73).

17 Por. B. Skarga, Czas i trwanie. Studia o Bergsonie, Warszawa 2014, s. 180-181.

18 Рог. Л.В. Стародубцева, Разорванная вечность: парадокс времени в эсхатологической перспективе, [w:] Николай Александрович Бердяев, ред. В.Н. Порус, Москва 2013, s. 435.

19 Н.A. Бердяев, Я и мир..., s. 112 (wyd. pol., s. 75; cytat wedlug polskiego przekładu).
} 
(czasowienie istnienia) są dwoma odmiennymi porządkami: obiektywnym (sc. zobiektywizowanym) i subiektywnym (sc. egzystencjalnym) ${ }^{20}$. W doświadczeniu czasu powinien jednak zawierać się czas, który stanowiłby podstawę trwania, jego milczącego i niewypowiadalnego przeżywania. Tymczasem teraźniejszość (chwila) bywa najczęściej doświadczana jako budzące lęk zerwanie między tym, co już odeszło, a tym, co jeszcze nie nadeszło. Powstająca w tej chwili „wyrwa” może wręcz jawić się jako „nicość”, zawieszenie w próżni. Potrzeba zatem mostu, który połączyłby obydwa brzegi. Odnaleźć go można w doświadczeniu duchowym, które otwiera się na wieczność. „Czas nie jest zamkniętym kręgiem - podkreślał myśliciel - w który nic nie może przeniknąć z wiecznej rzeczywistości, ale czymś się otwierającym" ${ }^{21}$. Otóż dopowiadamy: wieczność „wydarzająca się” w świecie dać może wiele, tak wiele, ile źródło może dać rzece, a stwórczy Bóg dać siebie światu. W myśl tej „wizji początku” Bóg jest źródłem istnienia w czasie, zaś nasz sposób istnienia w nim jest pochodną "tragedii w życiu Boga”.

Jeśli więc uznać, że mit stanowi klucz do metafizyki historii, a tak przecież chce tę sprawę postrzegać Bierdiajew ${ }^{22}$, to należy przyjąć, że początek czasu zakorzenia się w wieczności, i można nawet powiedzieć więcej: to wieczność jest początkiem. A to zarazem znaczy, że na początku była wolność, która nieoddzielnie wiąże się z twórczością, albowiem ta ostatnia jest rozumiana jako nadawanie początku, „stwarzanie” nowości. W swej metafizyce wolności rosyjski filozof nawiązuje bezpośrednio (czyniąc jednak ukłon w stronę F.W.J. Schellinga) do mistyki Jakoba Böhmego:

Tajemna nauka Böhmego dotycząca Ungrund, bezdni, bezpodstawnej, ciemnej i irracjonalnej, poprzedzającej byt, jest próbą udzielenia odpowiedzi na podstawowe pytanie wszystkich pytań, a mianowicie pytanie o pochodzenie świata i pochodzenie zła. Cała nauka Böhmego dotycząca Ungrund tak się przeplata z nauką o wolności, że nie sposób ich rozdzielić, stanowią one jedną i tę samą naukę. Jestem również skłonny - przyznaje Bierdiajew - pojmować Ungrund jako pierwotną, niezdeterminowaną nawet przez Boga wolność meoniczną ${ }^{23}$.

W nadchodzącej - przewidywanej i przepowiadanej - nowej duchowości subiektywizacja ducha ludzkiego oznacza porzucenie sideł obiektywizacji na rzecz „czystego istnienia” (idem, Дyx..., s. 376).

${ }^{21}$ Idem, Смысл..., s. 79 (wyd. pol., s. 47; cytat według polskiego przekładu, częściowo zmodyfikowany).

22 Ibidem, s. 67 (wyd. pol., s. 41).

23. Idem, Из этюдов о Якове Беме. Этюд I: Учение об Унгрунде и свободе, „Путь” 1930, nr 20, s. 57. 
Porządek pojęciowy układa się zatem następująco: wolność - twórczość - nowość - wyjście poza czas. Pozostając w zgodzie z przyjętymi założeniami, myśliciel może zatem twierdzić, że źle ukierunkowana wolność, z jaką mamy do czynienia w świecie zobiektywizowanym, pogłębia dualizm dwóch światów, a mianowicie utwierdza rozróżnienie poziomu duchowego i pochodnego, Boskiego i stworzonego. To domaga się od człowieka jako twórcy i kont ynuatora dzieła stwórcy przezwyciężenia - zaistniałego u zarania świata i ludzkości - fundamentalnego rozdarcia. Nie powinniśmy się przeto dziwić, że jedynie mit, za sprawą łączącej mocy symboli (bowiem mit to „symbol rozwinięty w formie opowieści” - Paul Ricoeur) ${ }^{24}$, jest w stanie podołać temu wyzwaniu ${ }^{25}$. Co więcej, symbol i mit, a więc i świadomość mitologiczna, która znajduje swój wyraz w religii i filozofii (zresztą nie tylko religijnej), jawią się jako narzędzia duchowego i bytowego wzrostu ku doskonałości:

Świadomość symboliczna czyni rozróżnienie między symbolem a realnością i dlatego właśnie kieruje nas ku realnościom, ku realizacji życia duchowego. Prawdziwy symbolizm oznacza również przejście do prawdziwego realizmu duchowego, do zamiany symboli przez realności, życia wtórnego przez życie pierwotne, do przemiany życia, do doskonałości duchowej, doskonałości Ojca niebieskiego ${ }^{26}$.

Ostatecznie więc celem życia symbolicznego jest przeobrażenie „kultury w byt, symboli w realności", czyli osiągnięcie wyższego, integralnego życia ducha ${ }^{27}$.

Jak przekonuje Bierdiajew, chrześcijaństwo jest $\mathrm{z}$ gruntu mitologiczne i jednocześnie na wskroś historyczne ${ }^{28}$. Jak zatem połączyć te dwie różne perspektywy i dwa odmienne sposoby rozumienia świadomości chrześcijańskiej? Otóż ujmowana źródłowo historia odwołuje się do mitu, wszakże opowiada zawsze o historii pierwotnej (teogonii i kosmogonii) - co za Schellingiem podtrzymuje rosyjski myśliciel. Świadomość historyczna czerpie ze źródeł mitologicznych i tylko dzięki nim może prawdziwie wzrastać. O ile natomiast historię postrzega się jako proces odchodzenia od swoich mitologicznych korzeni, o tyle mamy już do czynienia ze stopniowym „pogrążaniem się w czas”, ujmowaniem jej natury jako „złej nieskończoności". Innymi słowy, tak rozumiana historia nie chce się kończyć. Tymczasem

24 „Mit będę traktował jako rodzaj symbolu, jako symbol rozwinięty $w$ formie opowieści i artykułujący się w czasie i w przestrzeni, które nie dadzą się przyporządkować czasom i przestrzeniom znanym z historii i geografii wedle wymogów metody krytycznej". Zob. P. Ricoeur, Symbolika zla, przeł. S. Cichowicz, M. Ochab, Warszawa 2015, s. 26.

25 Н.А. Бердяев, Философия свободного духа. Проблематика и апология христианства, ч. 1 , Paris 1927, s. 112.

$26 \quad$ Ibidem, s. 129.

27 Ibidem, s. 131.

28 O mitologiczności: idem, Философия.., s. 113-114. O historyczności: idem, Смысл.., s. 42-47 (wyd. pol., s. 28-30). 
początek "przywołuje" koniec jako swoje spełnienie. Symbol staje się mostem łączącym początek $z$ końcem, umożliwia przekroczenie rozziewu, lub mówiąc inaczej - oswaja metafizyczny hiatus, z jakim przyszło borykać się człowiekowi historycznemu, a tym samym wprowadza na powrót metafizykę w sam rdzeń ludzkiej historii. To dlatego Bierdiajew mówi o metafizyce eschatologicznej.

$\mathrm{W}$ porządku istnienia historycznego mamy natomiast do czynienia z pierwotnym, przedhistorycznym "upadkiem w czas" - o czym opowiada starożytny mit i co skutkuje rozerwaniem czasu na przeszłość, teraźniejszość i przyszłośćc ${ }^{29}$. Czas taki staje się "upadłym” produktem obiektywizacji, czasem zobiektywizowanym. Doświadczanie go przez człowieka jest naznaczone „bólem czasu” ${ }^{30}$. Należy więc dokonać zmiany perspektywy i uznać, że prawdziwym kluczem do zrozumienia historii jest czas egzystencjalny. W takim zaś ujęciu historia świata i ludzkości staje się jednocześnie „losem człowieka” - by tak rzec: głębinowym, duchowym ujęciem własnej, zakorzenionej w podmiocie historyczności. Tym samym eschatologia historii, nic nie tracąc ze swej „zewnętrzności”, przechodzi w wymiar wewnętrzny, staje się eschatologią indywidualną (bynajmniej nie indywidualistyczną!). W każdej takiej chwili, w każdym „momencie" kairotycznym podmiot ludzki może więc doświadczyć objawienia ducha: wieczności ustanawiającej metahistoryczną jedność początku i końca.

\section{Kultura transcendencji}

Zwrócenie się ku duchowi (pojęcie to, przyznajmy, jest współcześnie przywoływane z pewną dozą niechęci) i ku wieczności (i znów, rzec można, obecnie perspektywa ta nie znajduje zbyt wiele przychylności) dokonuje się w twórczym dążeniu bytu ludzkiego ${ }^{31}$. Odwołuje się przy tym do symbolicznego sposobu rozumienia świata i w swej aktowości na nim się opiera. Dlatego też ważna jest filozofa kultury; wszak to ona właśnie posiada naturę symboliczną par excellence. Religia, stanowiąca rdzeń kultury (nie należy bowiem zapominać, że ta ostatnia wyrasta z kultu), nadaje jej znaczenie soteriologiczne. Człowiek jako „duchowy twórca” jest tedy wezwany do realizacji wyższego sensu symbolu. Niepozbawione podstaw jest nawet mówienie o „apokaliptyce kultury”, pojmowanej jako docelowa i pełna realizacja

29 Idem, Смысл..., s. 95 (wyd. pol., s. 55).

30 Idem, $Я$ и мup..., s. 105 (wyd. pol., s. 70).

3 Rehabilitacji pojęcia ducha (eksplikacji realności ducha) w myśli współczesnej Bierdiajew poświęcił przywoływane powyżej dzieło Дух и реальность. Основы богочеловеческой духовности (1937). 
symbolu, to znaczy przezwyciężenie świata obiektywizacji, wkroczenie w wymiar ducha i osiągnięcie wolności eschatycznej. (Jak wiemy, symbolizm jest stanowiskiem realistycznym, przy jednym zastrzeżeniu: mianowicie musi dla nas pozostać jasne, że same symbole nie są realnościami, a contrario, brane same w sobie są tylko narzędziami obiektywizacji).

Powracając do problemu czasu, należy podkreślić, że popadanie w czasowość, „upadek w czas” i tym samym poddanie się władzy przemijalności, „złej nieskończoności" - $z$ jednej strony - i przekraczanie czasowości ku wieczności w postaci "twórczego wzlotu" - z drugiej - są dwiema skrajnie odmiennymi postawami ludzkimi. Ekstatyczność aktu twórczego, jego ekspresywność i dostrzeganie w świecie śladu nieskończoności to zapewne romantyczny element $w$ Bierdiajewowskiej koncepcji twórczości ${ }^{32}$. Niezwykle ważne jest podkreślenie, że w takim ujęciu twórczość posiada naturę duchową. Wszelako sama konieczność oddzielenia inicjującego aktu podmiotowego od rezultatu przedmiotowego, a także nieuniknioność tego rozróżnienia, i, co gorsza, uprzedmiotowienie samego aktu twórczego, prowadzą do tragedii twórczości. Wysiłek zdążający wzwyż jest naznaczony groźbą takiej "porażki”, stale towarzyszy mu niebezpieczeństwo oziębienia i zastygnięcia aktu twórczego. Proces ten dokonuje się zresztą z fatalistyczną siłą bezwładności, pod naciskiem „złego", zobiektywizowanego czasu.

Jak już wiemy, orbity czasu kosmicznego są wpisywane w styczną czasu historycznego. Historia naturalna staje się tym samym - a przynajmniej powinna stać się - częścią historii ludzkiej. Mechanika zachodzących w świecie procesów domaga się innej dynamiki: działania ducha. W przeciwieństwie do perspektywy stającego się kosmosu i zamkniętej w sobie historii czas egzystencjalny jawi się jako wydarzenie "punktowe", odsyła do wieczności. W tym sensie każda taka chwila, która jest wtargnięciem wieczności w czas, jest i powinna być twórcza: metahistoryczna i eschatologiczna. W egzystencjalnym przeżyciu chwili dochodzi zatem do głosu wymykająca się wewnątrzświatowym i uprzedmiotowionym zależnościom pierwotna wolność ducha ludzkiego: w swojej twórczości człowiek niejako pozwala wydarzyć się wolności w świecie. Ryzykując powtórzenie, zapytajmy raz jeszcze: skąd ona pochodzi i gdzie leżą jej źródła? ${ }^{33}$ Otóż u podstaw myślenia Bierdiajewa spotykamy metafizyczny „mit o wolności”, przedstawiający swoistą odyseję wolności. Najogólniej mówiąc, metafizyczne dzieje wolności rozpoczynają się od meonicznej, ungrundowej pra-wolności i, przez wolność „upadłą w czas”, prowadzą do wolności eschatycznej - wolności aktywnie i twórczo przepracowanej. Tylko

32 O roli romantyzmu w myśli М. Bierdiajewa pisze В.В. Зеньковский, История русской философии, т. 2, Москва-Ростов-на-Дону 1999, s. 344-345, 364.

3 Por. przyp. 23. 
pierwszą i ostatnią należy uznać za wolność w sensie właściwym; w istocie bowiem stanowią one jedną i tę samą - choć rozważaną na różnych poziomach - wolność, którą z kolei powinno się przeciwstawić wolności wtórnej, przejawionej w świecie "upadłym”, fenomenalnym, a zatem wolności skazanej na nieustanne podejmowanie wyborów „po tej stronie” dobra i zła.

Co wobec tego ostatecznie dokonuje się w czasie egzystencjalnym? Odpowiadając wprost, można stwierdzić tyleż lapidarnie, co enigmatycznie: następuje koniec świata i historii. I bynajmniej nie jest to twierdzenie negatywne: „Koniec oznacza także zwycięstwo czasu egzystencjalnego nad czasem historycznym i kosmicznym. Tylko w czasie egzystencjalnym, mierzonym napięciem i intensywnością stanów podmiotu, może się otworzyć wyjście ku wieczności" ${ }^{34}$.

Pomiędzy indywidualną (osobową) a uniwersalną (historyczną) perspektywą eschatologiczną "powstaje pusty czas" ${ }^{35}$. Jak rozumieć to sformułowanie? Zapewne można przyjąć, że jest to czas znajdujący się na rozdrożu między kresem losu indywidualnego a końcem uniwersalnym, swoiste przesunięcie czasowe, w którego wyniku śmierć indywidualna - w dotychczasowym doświadczeniu - wyprzedza zamknięcie historii świata. Paradoksalnie koniec czasu dokonuje się jednocześnie „w czasie" i „poza czasem”, co rzecz jasna uniemożliwia jego dyskursywne ujęcie. Niekiedy jednak to, co wymyka się porządkowi dyskursywnemu, może zostać uświadomione $w$ doświadczeniu duchowym: a tym samym stać się pokarmem myśli. Wyłącznie tedy w czasie egzystencjalnym możliwe jest przybliżenie się do „tajemnicy dni ostatnich". Podobnie zatem jak w perspektywie egzystencjalnej, tak i w wypadku eschatologicznej ant ynomii końca czasu to, co indywidualne, łączy się z tym, co uniwersalne. Teraźniejszość przeżywana jako chwila - kairos w sensie egzystencjalnym - jest zawsze końcem starego i narodzinami nowego świata, ponieważ każdorazowo staje się uobecnieniem wieczności. W ramach zaś antynomii końca czasu los indywidualny pozostaje związany z losem wspólnym, uniwersalnym. Ani jednostka (osoba ludzka), ani wszechświat (ludzkość) nie mogą zatem znaleźć swego spełnienia w oderwaniu od siebie nawzajem. Co zatem mogłoby stanowić zwornik dla obydwu członów tej antynomii? Podpowiedź podsuwa zagadnienie: „ja” i wszechświat, czyli założona u podstaw samej tej koncepcji odpowiedniość mikro-i makrokosmosu. A to zarazem znaczy, że ani jednostka, ani ludzkość nie są w stanie osiągnąć swego celu i losu ostatecznego bez przyjęcia solidarności soteriologicznej: w "odosobnieniu” zanika "osoba", nie ma kogo zbawiać.

3 H.A. Бердяев, Onыı..., s. 275 (wyd. pol., s. 156; cytat według polskiego przekładu).

35 Ibidem, s. 277 (wyd. pol., s. 158). 
Przeżywanie i pojmowanie czasu wiążą się zatem z doświadczeniem duchowym. Można wręcz mówić o duchowym doświadczeniu czasu. Jakie ma to znaczenie dla interesującego nas problemu czasowości istnienia? Przywołajmy wpierw wyznanie samego myśliciela: „Nie myślę dyskursywnie, nie tyle dochodzę do prawdy, co raczej od prawdy wychodzę" ${ }^{36}$. Przy takim podejściu filozofia ma za zadanie „rozjaśnianie” prawd danych w doświadczeniu duchowym. Należy ją zatem uznać za intelektualny proces odsłaniania treści przeżytych, i to zarówno przez osobę indywidualnie, jak i przez ludzkość - wspólnotowo. W przeciwieństwie bowiem do fragmentaryczności, jaką jest $z$ konieczności skażone poznanie fenomenalne, przeżycie duchowe i oparte na nim poznanie noumenalne ujmują rzeczywistość w jej całości (przypomnijmy, że jej zwornikiem pozostaje „mit podstawowy”, jakim jest idea Bogoczłowieczeństwa) ${ }^{37}$. Filozofia jako rozjaśnianie - albo inaczej: filozofia jako rozwijanie intelektualnych treści zawartych $\mathrm{w}$ doświadczeniu metafizycznym - powinna przeto opierać się na "symbolice życia duchowego"; co notabene pozostaje również jedną $\mathrm{z}$ głównych przesłanek filozofii Boga ${ }^{38}$. Kultura ludzka, a zatem świat symboliczny, stanowi część porządku czasowego, ale mimo to jednocześnie go przekracza, przede wszystkim bowiem otwiera się "na przyszłość i na wieczność". Właściwie pojęty świat ludzki jest więc kulturą transcendencji, na gruncie której staje się możliwe „osądzanie” wartości: uwiecznianie „dobrego" i przezwyciężanie „złego” czasu.

\section{Bibliografia}

Bierdiajew N.A., Egzystencjalna dialektyka Boga i człowieka, przeł. H. Paprocki, Kęty 2004. Bierdiajew N.A., Królestwo Ducha i królestwo cezara, przeł. H. Paprocki, Kęty 2003.

Bierdiajew N.A., Rozważania o egzystencji. Filozofia samotności i wspólnoty, przeł. H. Paprocki, Kęty 2002.

Bierdiajew N.A., Sens historii. Filozofia losu człowieka, przeł. H. Paprocki, Kęty 2002.

Bierdiajew N.A., Zarys metafizyki eschatologicznej. Twórczość $i$ uprzedmiotowienie, przeł. W. i R. Paradowscy, Kęty 2004.

Dupré L., Inny wymiar. Filozofia religii, przeł. S. Lewandowska-Głuszyńska, Kraków 2003. Heidegger M., Bycie i czas, przeł. B. Baran, Warszawa 2008.

36 Ibidem, s. 164 (wyd. pol., s. 17; cytat według polskiego przekładu).

37 Zapewne można by przyjąć, że jest to też próba komentarza (zresztą, jak wiele innych, niesatysfakcjonującego) do naszej marginalnej uwagi dotyczącej metafizycznego problemu jedności i wielości ujętego $w$ aspekcie przeżycia duchowego.

3月 Por. Н.А. Бердяев, Царство Духа и царство Кесаря, [w:] idem, Царство Духа и царство Кесаря, Moskwa 1995, s. 297 (wyd. pol. Królestwo Ducha i królestwo cezara, przeł. H. Paprocki, Kęty 2003, s. 19). 
Kierkegaard S., Wprawki do chrześcijaństwa. Anti-Climacusa nr I, II, III, przeł. A. Szwed, Kęty 2002.

Marcel G., Homo viator. Wstęp do metafizyki nadziei, przeł. P. Lubicz, Warszawa 1984.

Ricoeur P., Symbolika zła, przeł. S. Cichowicz, M. Ochab, Warszawa 2015.

Skarga B., Czas i trwanie. Studia o Bergsonie, Warszawa 2014.

Tillich P., Teologia systematyczna, t. 3, przeł. J. Marzęcki, Kęty 2005.

Бердяев Н.А., Царство Духа и царттво Кесаря, Москва 1995.

Бердяев Н.А., Дух и реальность. Основы богочеловеческой духовности, [w:] Н.А. Бердяев, Дух и реальность, Москва 2006.

Бердяев Н.А., Экзистенциальная диалектика Божественного и человеческого, [w:]

Н.А. Бердяев, О назначении человека, Москва 1993.

Бердяев Н.А., Философия свободного духа. Проблематика и апология христианст$в a$, ч. 1, Paris 1927.

Бердяев Н.А., Из этюдов о Якове Беме. Этюд I: Учение об Унгрунде и свободе, „Путь” 1930, nr 20.

Бердяев Н.А., Я и мир объектов. Опыт философии одиночества и общения, [w:] Н.А. Бердяев, Дух и реальность, Москва 2006.

Бердяев Н.А., Опыт эсхатологической метафизики. Творчество и объективация,

[w:] Н.А. Бердяев, Царство Духа и царттво Кесаря, Москва 1995.

Бердяев Н.А., Смысл истории. Опыт философии человеческой судьбы, Pa ris 1969.

Бердяев Н.А., Царство Духа и царство Кесаря, [w:] Н.А. Бердяев, Царство Духа и царство Кесаря, Moskwa 1995.

Зеньковский В.В., История русской философии, т. 2., Москва- Ростов-на-Дону 1999. Стародубцева Л.В., Разорванная вечность: парадокс времени в эсхатологической перспективе, [w:] Николай Александрович Бердяев, ред. В.Н. Порус, Москва 2013.

\section{Informacja o Autorze}

Dr hab. Leszek Augustyn, prof. UJ (Лешек Аугустын) - filozof i religioznawca, pracownik Instytutu Filozofii Uniwersytetu Jagiellońskiego w Krakowie.

e-mail: l.augustyn@iphils.uj.edu.pl

https://orcid.org/0000-0002-8694-8702 